\title{
Evaluation of Effectiveness of Biologically Synthesized Silver Nanoparticles of Eucalyptus globules Leaf Extract against Pathogenic and Acne-inducing Bacteria
}

Kalpana Thakur, Indu Bala, Rajeshwer, Mamta Devi and Arvind Kumar Bhatt*

Department of Biotechnology, Himachal Pradesh University, Summerhill, Shimla-171005, India

\begin{abstract}
The present research was aimed to investigate the antimicrobial potential of biologically synthesized silver nanoparticles from leaf extract of Eucalyptus globules against certified pathogenic microorganisms Bacillus cereus, Escherichia coli, Pseudomonas aeruginosa, Salmonella typhi, Shigella, Staphylococcus aureus and also acne inducing bacteria, using agar well diffusion method. Highest antimicrobial activity $(20 \mathrm{~mm})$ against Staphylococcus aureus was recorded with methanolic extract of Eucalyptus globules leaves in comparison to other extracts. Phytochemical analysis of crude extract revealed the presence of alkaloids, carbohydrates, flavonoids, saponins, steroids, soluble starch, terpenoids and tannins. The silver nanoparticles synthesized from the methanolic extract using silver nitrate showed peak at $375 \mathrm{~nm}$. The characterization of nanoparticles for size, shape and nature using X-ray diffraction (XRD) and Atomic Force Microscopy (AFM) revealed that the particle size ranged between $15-71 \mathrm{~nm}$. The efficacy of synthesized nanoparticles was checked against four acne inducing isolates and also other certified pathogenic strains. It was found that the overall effectiveness of AgNp's was much higher than crude extract and also exceptionally high in some cases (i.e. higher than positive control). The AgNp's were quite effective against the pathogenic strains even at very low concentration $(0.0097 \mu \mathrm{g} / 100 \mathrm{ml})$. The results indicated a marked improvement in effectiveness of plant extracts at nanoscale. Further Eucalyptus leaf extract has potential to be used as alternate to synthetic medicines as they are relatively cheaper and safer to use with less or no side effects but only after intensive R\&D and clinical trials.
\end{abstract}

Keywords: Eucalyptus globules; AgNp's; X-ray diffraction; AFM; UV visible spectroscopy

\section{Introduction}

Plants are the natural sources of medicinal compounds. Over half of all modern clinical drugs are of natural origin which plays an important role in drug development programs in various pharmaceutical industries. The knowledge of structure, nature and mode of action/ applicability of phytoconstituents is desirable as it could be used for the synthesis of complex chemical substances as an alternate for synthetic drugs. These chemicals although produced by plants to protect themselves but many of these phyto-chemicals can also protect humans from various diseases [1]. Himalayan region possess unique climatic conditions which is an ideal habitat for the natural growth of variety of medicinal plants and herbs [2]. According to World Health Organization (WHO), about $80 \%$ of the global population depends on traditional medicine for their primary healthcare needs. Due to increase in the resistance of pathogenic microorganisms towards antibiotics, scientists are making efforts to explore antimicrobial activity of different herbal extracts in different regions of the world. This has resulted in exploration of new and promising biologically active compounds of plant origin having immense utility in herbal medicine [3]. The efficacy of plant extracts against various pathogenic microbes can be enhanced using biotechnological interventions including nanotechnology, one of the most active areas of researches in modern day science and technology [4].

Of various medicinal plants used in traditional medicinal system even today, Eucalyptus globules, the plant used for energy plantation was selected based on the prior results in our laboratory. The plant Eucalyptus globules, belonging to family Myrtaceae is world's one of the most widely planted genera [5]. Commonly called as Tasmanian Blue Gum (Safeda), is very fast growing evergreen tree, bearing pendant leaves, native to Tasmania and South-East Australia. Among all the 600 species Eucalyptus globules is the most widely cultivated in Subtropical and Mediterranean regions [6]. The plant has various medicinal properties such as antidiabetic, antioxidant, antimicrobial, and insecticidal. 1,8-cineole, the major constituent of volatile oil of the E. globules is a strong inhibitor of cytokines. It is suitable for the treatment of airway inflammation in bronchial asthma and other steroid-sensitive disorders [7]. Leaf extracts of Eucalyptus is being used in cosmetic formulations and has also been approved as food additive [8].

Local herbal practioners have used and are still using the plant parts especially leaves of Eucalyptus for curing several diseases. Efforts are made in the present investigation to evaluate the antimicrobial potential of leaf extract of Eucalyptus growing in Shimla against the certified pathogenic bacteria and also against acne inducing microbes.

\section{Materials and Methods}

\section{Collection of plant material}

Fresh leaves of the Eucalyptus globules were collected from local areas of Shimla district in Himachal Pradesh (India). The leaves were washed with distilled water, dried in shade, powdered using pestle and mortar and stored in air tight container until further use.

*Corresponding author: Arvind Kumar Bhatt, Department of Biotechnology Himachal Pradesh University, Summerhill, Shimla-171005, India, Tel: 9418450009 ; E-mail: bhtarvind@yahoo.com

Received: April 28, 2017; Accepted: May 15, 2017; Published: May 22, 2017

Citation: Thakur K, Bala I, Rajeshwer, Devi M, Bhatt AK (2017) Evaluation of Effectiveness of Biologically Synthesized Silver Nanoparticles of Eucalyptus globules Leaf Extract against Pathogenic and Acne-inducing Bacteria. J Nanomed Nanotechnol 8: 443. doi: 10.4172/2157-7439.1000443

Copyright: ( 2017 Thakur K, et al. This is an open-access article distributed under the terms of the Creative Commons Attribution License, which permits unrestricted use, distribution, and reproduction in any medium, provided the original author and source are credited. 
Citation: Thakur K, Bala I, Rajeshwer, Devi M, Bhatt AK (2017) Evaluation of Effectiveness of Biologically Synthesized Silver Nanoparticles of Eucalyptus globules Leaf Extract against Pathogenic and Acne-inducing Bacteria. J Nanomed Nanotechnol 8: 443. doi: 10.4172/21577439.1000443

Page 2 of 8

\section{Test organisms used}

The pathogenic microorganisms i.e. Escherichia coli, Pseudomonas aeruginosa, Salmonella typhi, Shigella, Staphylococcus aureus and Bacillus cereus and were procured from Department of Microbiology, Indira Gandhi Medical College and Hospital (IGMC), Shimla (H.P.).

\section{Antimicrobial agent}

Antibiotics were used as positive control (Table 1).

\section{Preparation of plant extract}

The powdered sample was used for the solvent extraction using cold percolation method. Dried powdered material was separately added in solvents (1:10 ratio) separately in $250 \mathrm{ml}$ Erlenmeyer flask. Different solvents i.e. petroleum ether, chloroform, acetone, methanol and water were used for extraction and the crude extracts after evaporation were stored at $4^{\circ} \mathrm{C}$ for further use.

\section{Stock solutions}

The stock solutions of different extracts were prepared using $10 \%$ of DMSO (Dimethyl sulfoxide), the universal solvent in such a way that the final concentration of plant extract was $100 \mathrm{mg} / 1000 \mu \mathrm{l}$. The stock solutions were stored at $4^{\circ} \mathrm{C}$ for further use.

\section{Determination of antimicrobial activity}

The effect of plant extracts on the bacterial strains (Clinical isolates) was measured by agar well diffusion method. The minimum concentration of plant extract required to inhibit the growth of microorganism was checked by Resazurin dye method [9]. The MIC value of the most effective extract i.e. methanolic extract was determined against all pathogenic microbes using decreasing concentrations of methanolic extract in the range of $0.0048-10 \mathrm{mg} / 100 \mu \mathrm{l}$.

\section{Phytochemical analysis}

Phytochemical analysis of plant extract for the identification of phytochemicals like carbohydrates, soluble starch, tannins, alkaloid, steroids, saponin, terpenoids and flavonoids was carried out using different methods.

\section{Tests for carbohydrate}

Fehling's test: Equal volume of Fehling A (copper sulfate in distilled water) and Fehling B potassium tartrate and sodium hydroxide in distilled water) reagents were mixed along with plant extract and boiled in a water bath. Formation of brick red precipitates of cuprous oxide indicates the presence reducing sugar [10]

\section{Test for alkaloids}

Wagner's test (Solution of iodine in potassium iodide): Alkaloids give reddish brown precipitate with Wagner's reagent (1.27 g iodine

\begin{tabular}{|c|c|}
\hline Antibiotics used (Positive control) & Microorganism \\
\hline Tetracycline & Escherichia coli \\
\hline Tetracycline & Bacillus cereus \\
\hline Chloramphenicol & Salmonella typhi \\
\hline Gentamycin & Staphylococcus aureus \\
\hline Ciprofloxin & Shigella flexineri \\
\hline Gentamycin & Pseudomonas aeruginosa \\
\hline Erythromycin & Lab isolates (Acne sample) \\
\hline
\end{tabular}

Table 1: Following antibiotics were used as positive control in case of different microbes. mixed with $2 \mathrm{~g}$ potassium iodide and final volume made to $100 \mathrm{ml}$ with distilled water).

\section{Test for tannins}

Ferric chloride test: Extract giving blue-green color with 5\% ferric chloride solution indicated presence of tannins [11].

\section{Test for sterols and terpenoids}

Salkowski test: $2 \mathrm{ml}$ of concentrated sulfuric acid was added to the plant extract in a test tube. A yellow ring was formed at the junction, which turned red after one minute confirming presence of sterols and terpenoids [12].

\section{Test for flavonoids}

Shinoda test (magnesium hydrochloride ribbon test): On the addition of few fragments of magnesium ribbon and concentrated hydrochloric acid drop wise to the plant extract, the resultant pink scarlet, crimson red or occasionally green to blue color after few minutes indicated the presence of flavonoids [13].

\section{Test for saponins}

One gram of each plant extract was boiled with $5 \mathrm{ml}$ of distilled water and filtered the contents. To the filterate added about $3 \mathrm{ml}$ of distilled water and shaken vigorously for 5 minutes. The resultant frothing which persisted even on warming was taken as an evidence for the presence of saponins [14].

\section{Test for soluble starch}

Plant extract $(1 \mathrm{ml})$ boiled with $1 \mathrm{ml}$ of $5 \% \mathrm{KOH}$, cooled and acidified with $\mathrm{H}_{2} \mathrm{SO}_{4}$. Appearance of yellow color indicated the presence of soluble starch [15].

\section{Synthesis of Silver nanoparticle (AgNPs)}

The synthesis of silver nanoparticles was carried out using the methanolic extract of Eucalyptus globules as it was most effective among other solvents. $10 \mathrm{ml}$ plant extract $(10 \mathrm{mg} / 10 \mathrm{ml})$ was mixed with $1 \mathrm{mM}$ silver nitrate solution to make the final volume $100 \mathrm{ml}$. Thereafter the sample was incubated in dark for 24 hours at room temperature and the completion of reaction was measured using UVVisible spectrophotometer. The contents were centrifuged at 15,000 rpm for 20 minutes. The process was repeated by dispersion of pellets in water until colorless supernatant was obtained. Finally, the pellets were lyophilized and the sample were stored at $4{ }^{\circ} \mathrm{C}$ for further use. Characterization was carried out using X-ray diffraction (XRD) and Atomic Force Microscopy (AFM).

\section{Results}

\section{Effect of different concentrations of various extracts of Eucalyptus globules on pathogenic isolates}

Petroleum ether extract: Petroleum ether extract of leaves of $E$. globules showed activity against pathogenic isolates i.e. S. typhi, B. cereus and $P$. aeruginosa. The maximum zone of inhibition was against $P$. aeruginosa $(9 \mathrm{~mm})$ followed by $B$. cereus $(7.5 \mathrm{~mm})$ and least with S. typhi i.e. $(6.17 \mathrm{~mm})$ at the concentration of $4 \mathrm{mg} / 40 \mu \mathrm{l}$. When compared with positive control, the activity was quite low in case of crude extract (Figure 1).

Chloroform extract: The chloroform extract of E. globules leaves showed maximum activity against $B$. cereus $(12.23 \mathrm{~mm})$ which was 
Citation: Thakur K, Bala I, Rajeshwer, Devi M, Bhatt AK (2017) Evaluation of Effectiveness of Biologically Synthesized Silver Nanoparticles of Eucalyptus globules Leaf Extract against Pathogenic and Acne-inducing Bacteria. J Nanomed Nanotechnol 8: 443. doi: 10.4172/21577439.1000443

Page 3 of 8

better than positive control. However, in case of S. typhi and E. coli the crude leaf extract $(40 \mu \mathrm{l})$ was quite effective and comparable to the positive control. The least activity was shown against E. coli and P. aeruginosa $(7.12 \mathrm{~mm})$ at the concentration of $4 \mathrm{mg} / 40 \mu \mathrm{l}$ (Figure 2).

Acetone extract: Maximum zone of clearance was observed in case of $S$. typhi $(14.23 \mathrm{~mm})$ followed by $S$. aureus $(13.5 \mathrm{~mm})$ at a concentration of $4 \mathrm{mg} / 40 \mu \mathrm{l}$. The zone of inhibition (ZOI) in case of $S$. aureus $(13.5 \mathrm{~mm})$ was quite higher than positive control $(9 \mathrm{~mm})$. E. coli was least affected by acetone extract with only $9.71 \mathrm{~mm}$ clearance zone at $4 \mathrm{mg}$ concentration. The overall effectiveness of acetone extract of $E$. globules leaves was much higher against most of the microbes used and the recorded values were comparable to the positive control used i.e. 10 $\mathrm{mg} / 1000 \mu \mathrm{l}$ (Figure 3).

Methanol extract: The methanol extract was found most effective among others. The highest activity was shown against $S$. aureus $(20$ $\mathrm{mm})$ followed by $S$. typhi $(13.31 \mathrm{~mm})$ and B. cereus $(12 \mathrm{~mm})$ at a concentration of $4 \mathrm{mg} / 40 \mu \mathrm{l}$. It was least effective against $E$. coli and $P$. aeruginosa. The values when compared with the positive control were quite effective except in case of $P$. aeruginosa (Figure 4).

Aqueous extract: It was most effective against $S$. typhi and E. coli with clearance zone of $10.12 \mathrm{~mm}$ for each at the concentration of 4 $\mathrm{mg} / 40 \mu \mathrm{l}$. Least activity was observed in case of $P$. aeruginosa i.e.7.1 $\mathrm{mm}$ at $4 \mathrm{mg} / 40 \mu \mathrm{l}$. However, in comparison to the positive control, the effectiveness of the crude extract was quite low even at higher concentration (Figures 5-10).

Anti-acne potential of Methanolic extract: Based on the encouraging results obtained with the solvent extracts of $E$. globules leaves, efforts were made to evaluate the effectiveness of the most

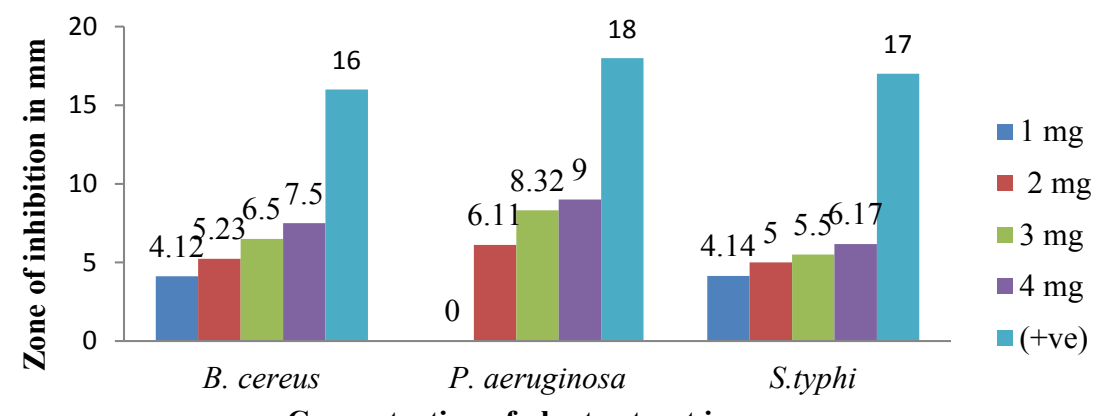

Concentration of plant extract in $\mathrm{mg}$

Figure 1: Antimicrobial activity of petroleum ether extract of $E$. globules.

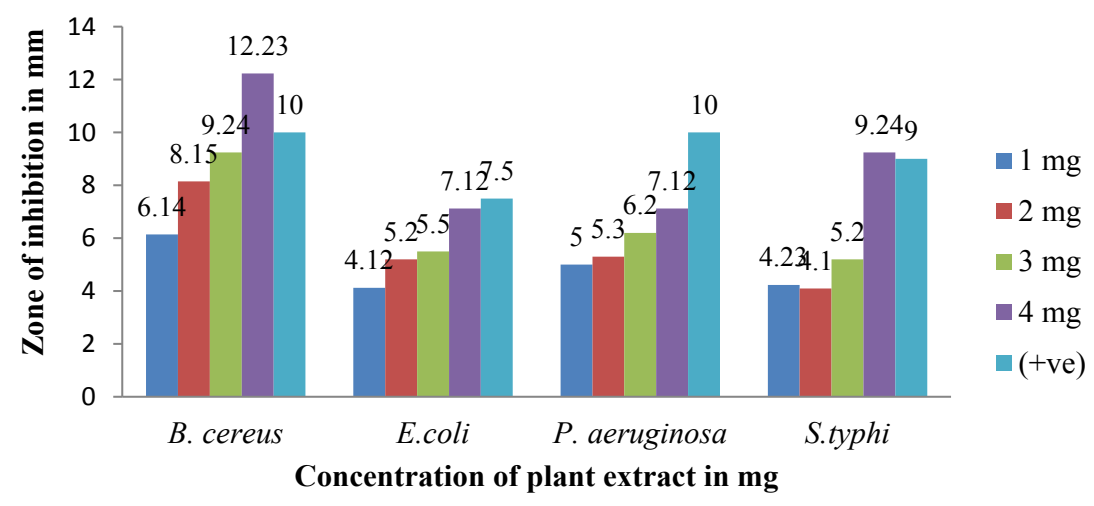

Figure 2: Antimicrobial activity of chloroform extract of E. globules.

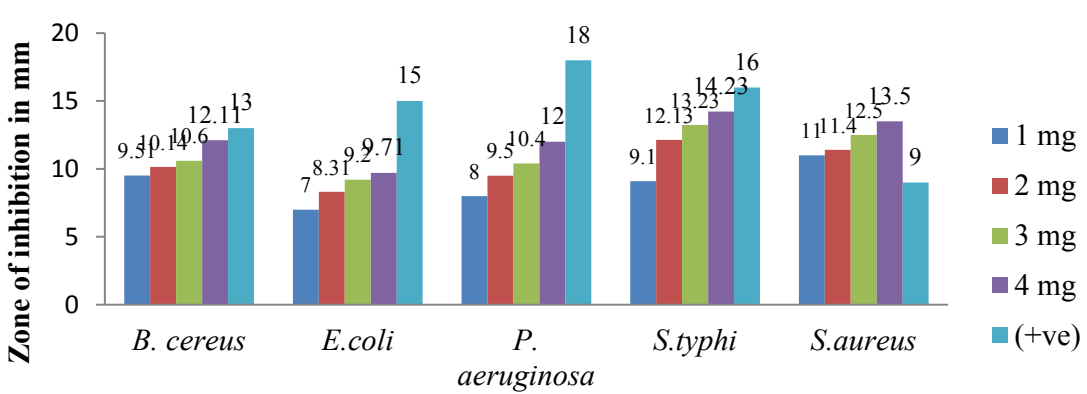

Concentration of plant extract in $\mathrm{mg}$

Figure 3: Antimicrobial activity of acetone extract of $E$. globules. 
Citation: Thakur K, Bala I, Rajeshwer, Devi M, Bhatt AK (2017) Evaluation of Effectiveness of Biologically Synthesized Silver Nanoparticles of Eucalyptus globules Leaf Extract against Pathogenic and Acne-inducing Bacteria. J Nanomed Nanotechnol 8: 443. doi: 10.4172/21577439.1000443

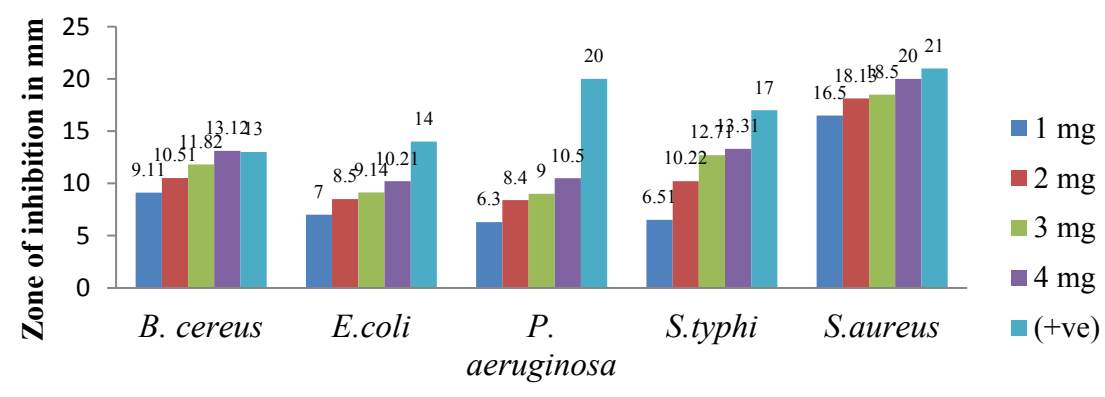

Concentration of plant extract in $\mathbf{m g}$

Figure 4: Antimicrobial activity of methanol extract of E. globules.

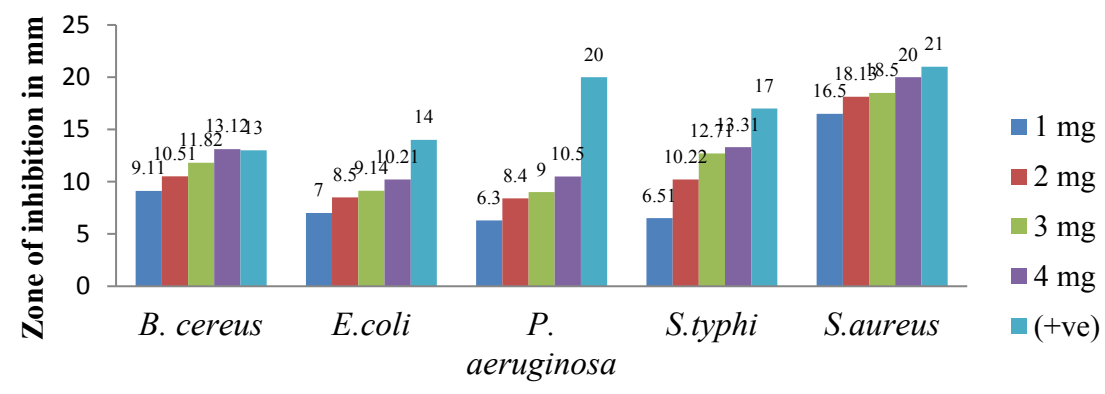

Concentration of plant extract in $\mathrm{mg}$

Figure 5: Antimicrobial activity of aqueous extract of E. globules.
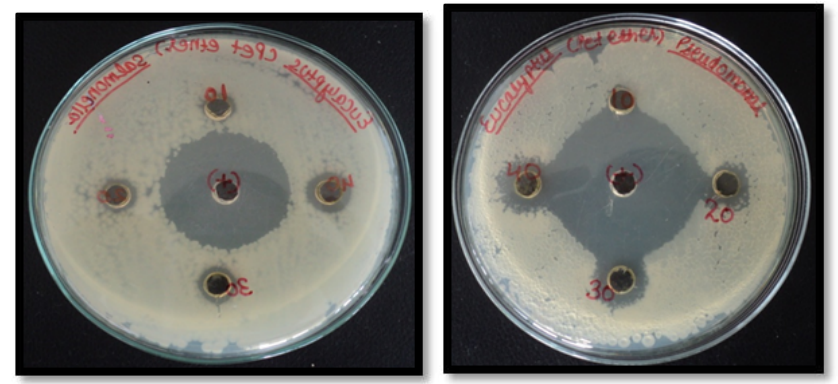

(A) S. typhi

(B) P. aeruginosa

Figure 6: Effect of petroleum ether extract of $E$. globules

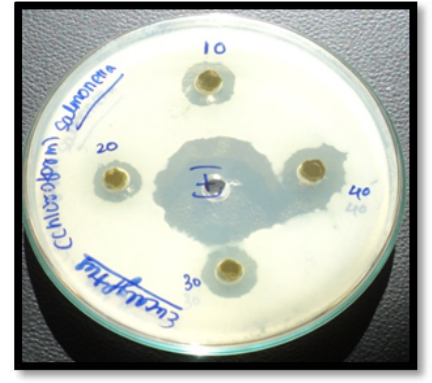

(A) S. typhi

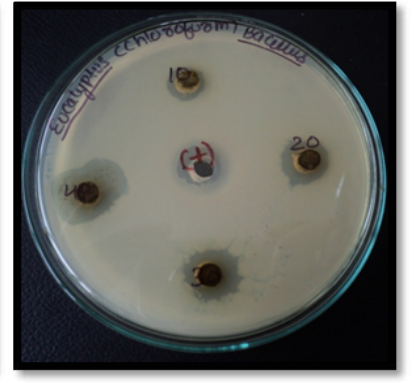

(B) B. cereus
Figure 7: Effect of chloroform extract of E. globules.

effective solvent extract i.e., methanolic extract of leaves of E. globules against the acne inducing microbes. The methanolic extract of Eucalyptus globules leaf extract showed good inhibitory action against

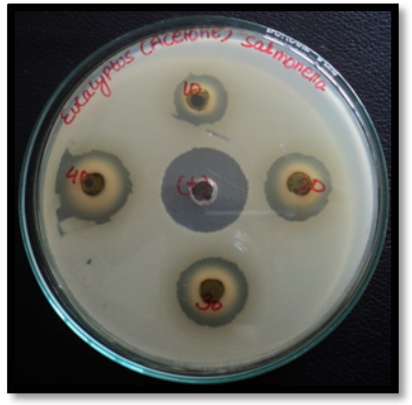

(A) S. typhi

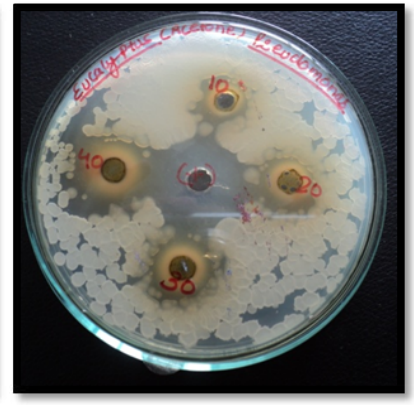

(B) $P$. aeruginosa
Figure 8: Effect of acetone extract of $E$. globules.

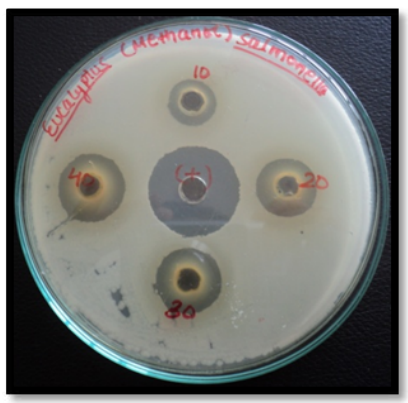

(A) S. typhi

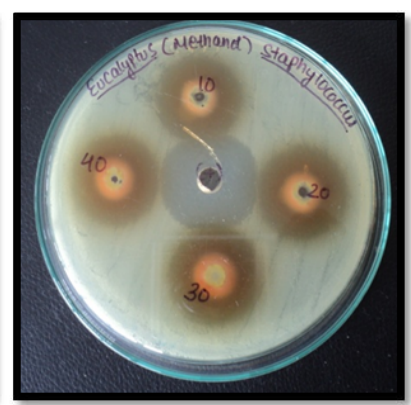

(B) S. aureus
Figure 9: Effect of methanol extract of E. globules.

all four microorganisms isolated from inflammatory papules (Table 2 and Figure 11). 
Citation: Thakur K, Bala I, Rajeshwer, Devi M, Bhatt AK (2017) Evaluation of Effectiveness of Biologically Synthesized Silver Nanoparticles of Eucalyptus globules Leaf Extract against Pathogenic and Acne-inducing Bacteria. J Nanomed Nanotechnol 8: 443. doi: 10.4172/21577439.1000443

Page 5 of 8

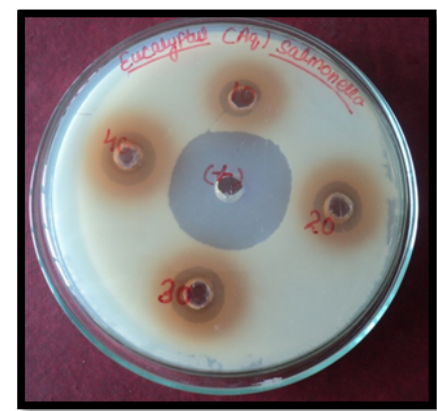

(A) S. typhi

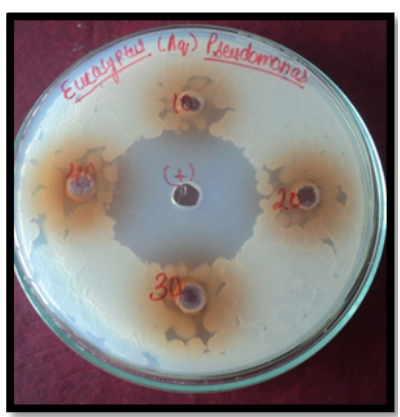

(B) P. aeruginosa
Figure 10: Effect of aqueous extract of E. globules.

\begin{tabular}{|c|c|c|c|}
\hline \multicolumn{4}{|c|}{ Zone of inhibition $\mathbf{( m m})$} \\
\hline Microorganisms & $\mathbf{4} \mathbf{~ m g / 4 0 ~} \boldsymbol{\mu l}$ & + Ve control & -Ve control \\
\hline Lab isolate 1 & $20 \mathrm{~mm}$ & $22 \mathrm{~mm}$ & - \\
\hline Lab isolate 2 & $12 \mathrm{~mm}$ & $25 \mathrm{~mm}$ & - \\
\hline Lab isolate 3 & $23 \mathrm{~mm}$ & $18 \mathrm{~mm}$ & - \\
\hline Lab isolate 4 & $14 \mathrm{~mm}$ & $17 \mathrm{~mm}$ & - \\
\hline
\end{tabular}

Table 2: Antimicrobial activity of methanolic extract on acne microflora

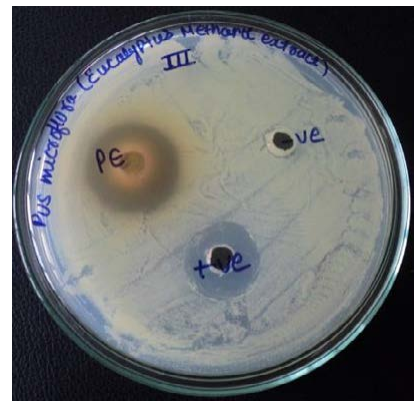

(A) Lab isolate 3

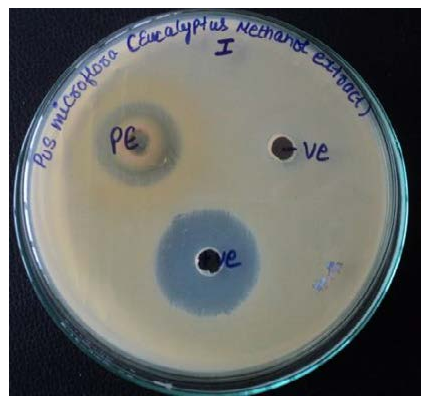

(B) Lab isolate 1
Figure 11: Anti-acne potential of methanolic extract.

Phytochemical analysis of E. globules (methanolic extract of leaf): Phytochemical analysis of Eucalyptus globules leaf extract (Methanol) indicated the presence of various phytochemicals such as alkaloids, carbohydrates, flavonoids, saponins, steroids, soluble starch, terpenoids and tannins (Table 3 and Figure 12).

MIC of methanolic extract of Eucalyptus globules: MIC of methanolic extract of leaves of Eucalyptus globules was similar in case of B. cereus, S. typhi and S. aureus i.e., $0.078 \mathrm{mg} / \mu \mathrm{l}$. However 1.25 $\mathrm{mg} / 100 \mu \mathrm{l}$ concentration of the extract was required for Shigella. In the case of $P$. aeruginosa and E. coli the MIC was $0.019 \mathrm{mg} / 100 \mu \mathrm{l}$ and 0.039 $\mathrm{mg} / 100 \mu \mathrm{l}$ respectively (Table 4 and Figure 13).

\section{Characterization of Silver Nanoparticles (AgNPs)}

\section{UV-Visible spectrophotometry}

The exposure of silver ions to plant extracts results in its reduction which further leads to the synthesis of silver nanoparticles. This can be noticed by observing a color change which is due to the surface plasmon resonance (SPR) phenomenon. Synthesis of AgNp's was performed using the most effective methanolic extract of the leaves of E. globules. The recorded spectra of UV-VIS spectroscopic analysis of AgNp's showed peak at $375 \mathrm{~nm}$ which reflected the wavelength of surface plasmon resonance of silver quantum dots. The redox reaction

\begin{tabular}{|c|c|}
\hline \multicolumn{2}{|c|}{ E. globules } \\
\hline Compounds & Methanol extract \\
\hline Alkaloids & + \\
\hline Carbohydrates & + \\
\hline Flavonoids & + \\
\hline Saponins & + \\
\hline Soluble starch & + \\
\hline Steroids & + \\
\hline Tannins & + \\
\hline Terpenoids & + \\
\hline
\end{tabular}

Table 3: Phytochemicals analysis of Eucalyptus globules.

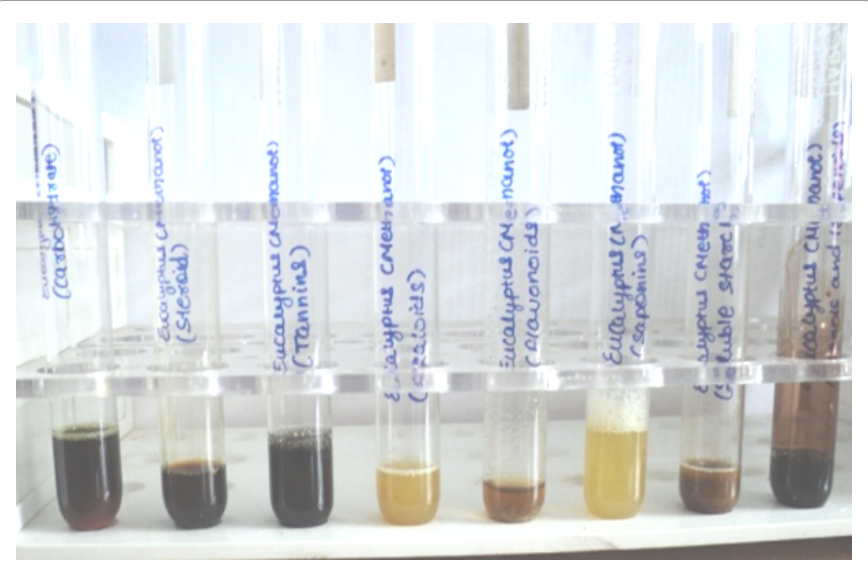

Figure 12: Phytochemical investigation of methanolic extract of $E$. globules.

\begin{tabular}{|c|c|c|c|c|c|c|}
\hline $\begin{array}{c}\text { Conc. of plant } \\
\text { extract } \\
(\mathrm{mg} / 100 \mu \mathrm{l})\end{array}$ & B. cereus & E. coli & P. aeruginosa & S. typhi & Shigella & S. aureus \\
\hline 10 & - & - & - & - & - & - \\
\hline 5 & - & - & - & - & - & - \\
\hline 2.5 & - & - & - & - & - & - \\
\hline 1.25 & - & - & - & - & - & - \\
\hline 0.625 & - & - & - & - & + & - \\
\hline 0.312 & - & - & - & - & + & - \\
\hline 0.156 & - & - & - & - & + & - \\
\hline 0.078 & - & - & - & - & + & - \\
\hline 0.039 & + & - & - & + & + & + \\
\hline 0.019 & + & + & - & + & + & + \\
\hline 0.0097 & + & + & + & + & + & + \\
\hline 0.0048 & + & + & + & + & + & + \\
\hline $\operatorname{MIC}(\mathrm{mg} / 100 \mu \mathrm{l})$ & 0.078 & 0.039 & 0.019 & 0.078 & 1.25 & 0.078 \\
\hline
\end{tabular}

-: no bacterial growth; +: bacterial growth

(All values are the mean of the experiments performed in triplicates).

Table 4: MIC of methanolic extract of Eucalyptus globules.

of silver ion and biomolecules of E. globules leaf extract was observed by the UV-VIS spectroscopy (300 to $700 \mathrm{~nm}$ ) (Figure 14).

\section{$\mathrm{X}$-ray diffraction (XRD)}

X-ray diffraction pattern recorded for the synthesized AgNp's as given in Figure 14 showed $2 \theta$ intense values with various degrees $\left(21.524^{\circ}, 23.822^{\circ}, 27.8210^{\circ}, 32.237^{\circ}, 46.2319^{\circ}, 54.820^{\circ}, 57.479^{\circ}\right.$, $\left.67.4507^{\circ}, 74.457^{\circ}, 76.745^{\circ}\right)$. These results correspond to (100), (100), (110), (110), (200), (211), (211), (221), (310) and (320) Bragg's reflection based silver nanoparticles. Size of the particle showing most intense peak was calculated as $33.69 \mathrm{~nm}$. Very clear, strong and intense XRD peaks observed with the plant extract confirm the crystalline nature 
Citation: Thakur K, Bala I, Rajeshwer, Devi M, Bhatt AK (2017) Evaluation of Effectiveness of Biologically Synthesized Silver Nanoparticles of Eucalyptus globules Leaf Extract against Pathogenic and Acne-inducing Bacteria. J Nanomed Nanotechnol 8: 443. doi: 10.4172/21577439.1000443

Page 6 of 8

of silver nanoparticles synthesized from methanolic leaf extract of $E$. globules (Figure 15).

\section{Atomic force microscopy (AFM)}

Silver nanoparticles synthesized from methanolic leaf the plant

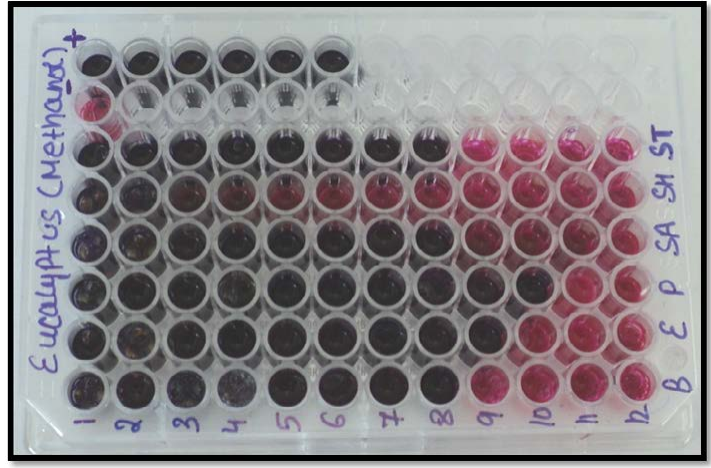

B: B. subtilis; E: E.coli; P: P. aeruginosa; SA: S. typhi; SH: Shigella; ST: S. aureus.

Figure 13: Microtitre plate showing MIC of methanolic extract of Eucalyptus globules.

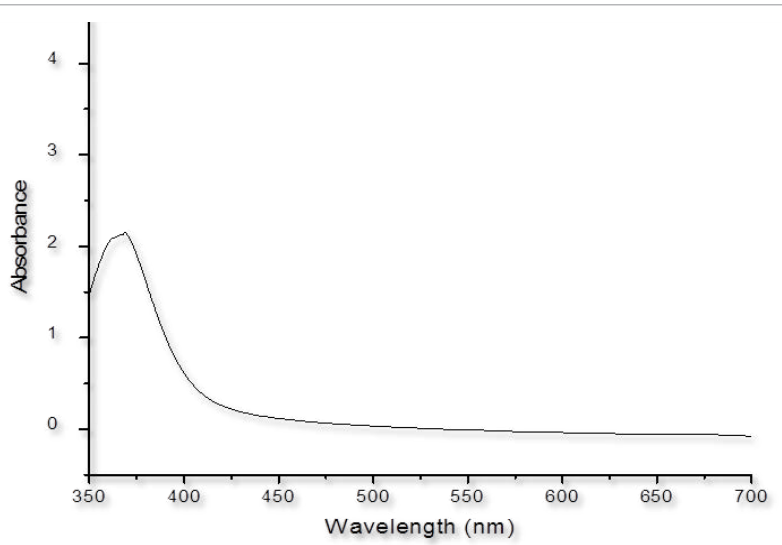

Figure 14: UV Visible spectra of AgNp's of Eucalyptus globules methanol leaf extract. extract were characterized for features like surface, shape and size using atomic force microscopy and surface morphology of the formulated silver nanoparticles was studied under AFM and the 3D image (AFM). The detailed analysis of the micrograph indicated that the particles were spherical in shape with smooth surface, without any pinholes or cracks. The size of the particle was in the range of 15-71 nanometers (Figure 16).

\section{Antibacterial activity of nanoparticles}

Antibacterial activity of synthesized (characterized) silver nanoparticles of methanol extract of Eucalyptus was tested against all pathogenic strains at the concentration of $100 \mathrm{mg} / 1000 \mu \mathrm{l}$ using agar well diffusion method. The results showed that antimicrobial activity of silver nanoparticles was much higher than the activity of crude extract (Figure 17).

Antibacterial assay of synthesized and characterized Eucalyptus silver nanoparticles was also tested against acne microbial flora. When compared with crude extract, it was found that there was tremendous increase in the antimicrobial activity of plant extract against acne microbial flora especially against Lab isolate-3 $(27 \mathrm{~mm})$ which was much higher than the positive control (Table 5 and Figure 18).

\section{MIC of silver nanoparticles}

MIC of AgNp's of methanolic extract of Eucalyptus globules against B. cereus, E. coli, S. aureus and S. typhi was similar i.e. $0.0097 \mathrm{mg} / 100 \mu \mathrm{l}$. However, in case of Shigella and P. aeruginosa, it was $0.019 \mathrm{mg} / 100 \mu \mathrm{l}$ When compared with crude extracts against these bacterial isolates, the effectiveness was exceedingly high (Table 6).

The effectiveness (antimicrobial activity) of synthesized AgNp's was exceptionally high against all pathogenic microbes with even very low concentration $0.0097 \mathrm{mg} / 100 \mu \mathrm{l}$ inhibiting the growth of these pathogenic microbes. However in case of $P$. aeruginosa, there was no difference in comparative effectiveness of both crude extract and AgNp's. In case of Shigella in place of $1.25 \mathrm{mg} / 100 \mu \mathrm{l}$ concentration of crude extract only $0.019 \mathrm{mg} / 100 \mu \mathrm{l}$ of AgNp's was required to inhibit the growth of the organism which speaks for the improvement of AgNp's over crude extract (Figure 19).

A comparative evaluation of antimicrobial potential of the crude extract of the leaves of E. globules revealed that the antimicrobial activity of solvent extract was higher in comparison to the aqueous

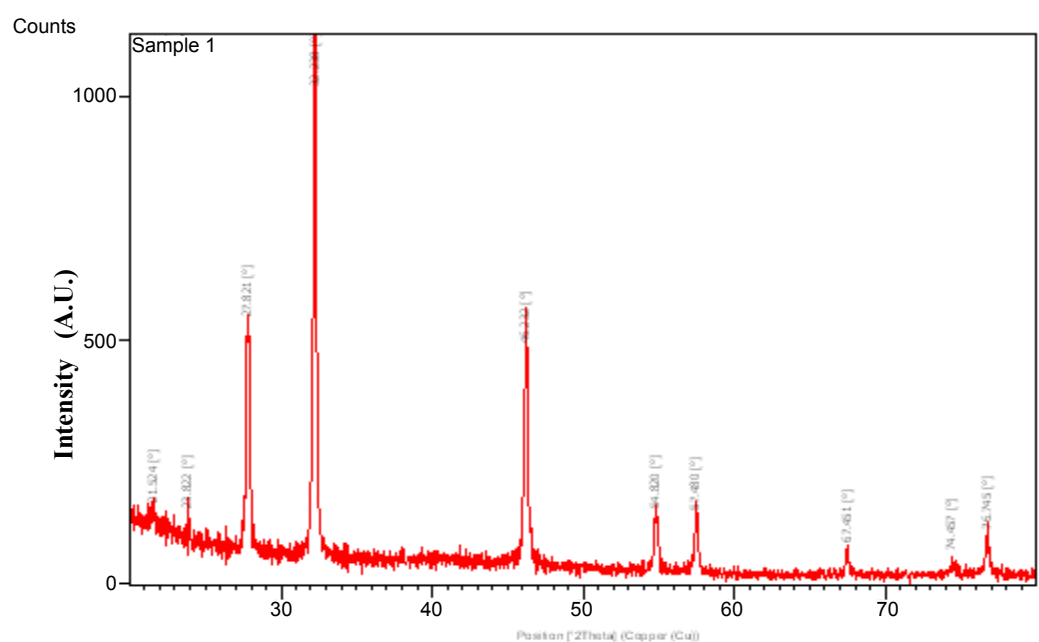

Figure 15: XRD pattern of AgNp's. 
Citation: Thakur K, Bala I, Rajeshwer, Devi M, Bhatt AK (2017) Evaluation of Effectiveness of Biologically Synthesized Silver Nanoparticles of Eucalyptus globules Leaf Extract against Pathogenic and Acne-inducing Bacteria. J Nanomed Nanotechnol 8: 443. doi: 10.4172/21577439.1000443

Page 7 of 8

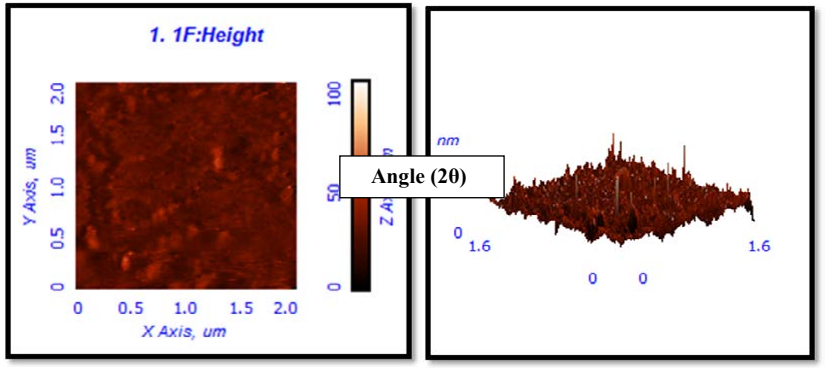

Figure 16: AFM - 2D and 3D images of synthesized silver nanoparticles.

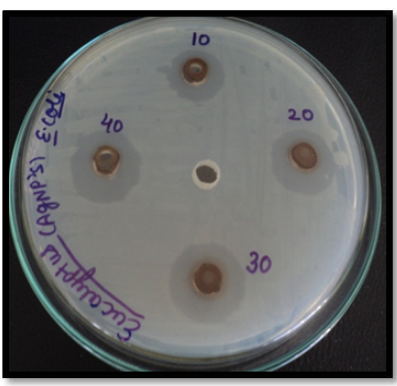

(A) E. coli

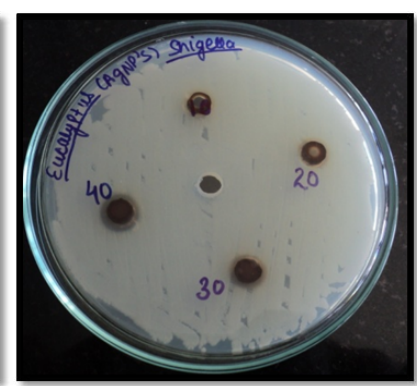

(B) Shigella
Figure 17: ZOI of AgNp's of methanol extract of Eucalyptus globules against pathogens.

\begin{tabular}{|c|c|c|c|}
\hline \multicolumn{4}{|c|}{ Zone of inhibition (mm) } \\
\hline Microorganism & $\begin{array}{c}\text { Crude extract } \\
(\mathbf{4 0} \mathbf{~ m g / 4 0} \mathbf{\mu l})\end{array}$ & $\begin{array}{c}\mathbf{A g N p} \mathbf{~} \\
(\mathbf{4 0} \mathbf{~ m g / 4 0} \boldsymbol{\mu l})\end{array}$ & Positive control \\
\hline Lab isolate 1 & $20 \mathrm{~mm}$ & $21 \mathrm{~mm}$ & $22 \mathrm{~mm}$ \\
\hline Lab isolate 2 & $12 \mathrm{~mm}$ & $22 \mathrm{~mm}$ & $25 \mathrm{~mm}$ \\
\hline Lab isolate 3 & $23 \mathrm{~mm}$ & $27 \mathrm{~mm}$ & $18 \mathrm{~mm}$ \\
\hline Lab isolate 4 & $14 \mathrm{~mm}$ & $16 \mathrm{~mm}$ & $17 \mathrm{~mm}$ \\
\hline
\end{tabular}

Table 5: Antimicrobial activity of AgNp's of methanol extract on acne micoflora

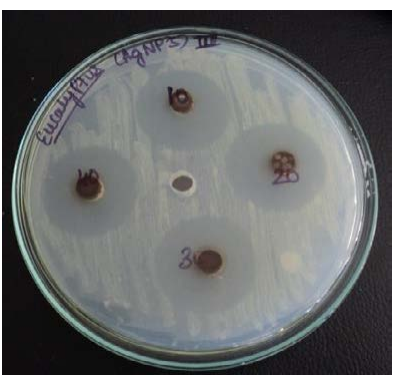

(A) Lab isolate 3

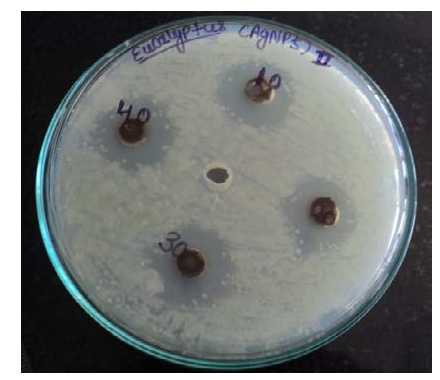

(B) Lab isolate 2
Figure 18: Effect of AgNp's of methanolic extract of Eucalyptus globules on acne microflora.

extract. However, the local traditional healers mostly use water as a medium for the preparation of decoction/medication dosages [16] and if the present method of extraction is used, the effectiveness will certainly increase manifold (Table 7).

Among different solvents, methanolic extract of Eucalyptus globules exhibited maximum antimicrobial activity against the tested human pathogens. The maximum activity was found in case of $S$. aureus $(20 \mathrm{~mm}$ at $40 \mu \mathrm{l})$ following $S$. typhi $(14.23 \mathrm{~mm}$ at $40 \mu \mathrm{l})$. Biljana et al. [17] have also reported the effectiveness of undiluted essential oil of $E$. globules for $S$. aureus (5-30 $\mu \mathrm{l}, 22-46 \mathrm{~mm})$, E. coli $(23-47 \mathrm{~mm})$ and $P$. aeruginosa (0-24 mm) which are comparable to the results obtained in this case.

As the methanolic extract of Eucalyptus globules emerged the best, its effectiveness was checked against microflora obtained from acne sample. Better inhibitory effect against microorganisms isolated from inflammatory papules in comparison to the pathogenic strains indicate that this plant can be used in various cosmetic formulations, as the natural content in the herbs does not have any side effects rather they enrich the body with nutrients and other useful minerals.

Presence of alkaloids, carbohydrates, flavonoids, saponins, steroids, soluble starch, terpenoids and tannins in crude methanolic extract of E. globules has also been reported earlier [18]. Phenolic compounds

\begin{tabular}{|c|c|c|c|c|c|c|}
\hline $\begin{array}{c}\text { Conc. of plant } \\
\text { extract } \\
(\mathrm{mg} / 100 \mu \mathrm{l})\end{array}$ & B. cereus & E. coli & P. aeruginosa & S. typhi & Shigella & S. aureus \\
\hline 10 & - & - & - & - & - & - \\
\hline 5 & - & - & - & - & - & - \\
\hline 2.5 & - & - & - & - & - & - \\
\hline 1.25 & - & - & - & - & - & - \\
\hline 0.625 & - & - & - & - & - & - \\
\hline 0.312 & - & - & - & - & - & - \\
\hline 0.156 & - & - & - & - & - & - \\
\hline 0.078 & - & - & - & - & - & - \\
\hline 0.039 & - & - & - & - & - & - \\
\hline 0.019 & - & - & - & - & - & - \\
\hline 0.0097 & - & - & + & - & + & - \\
\hline 0.0048 & + & + & + & + & + & + \\
\hline MIC (mg/100 $\mu \mathrm{l})$ & 0.0097 & 0.0097 & 0.019 & 0.0097 & 0.019 & 0.0097 \\
\hline
\end{tabular}

-: no bacterial growth; +: bacterial growth; All values are the mean of experiments performed in triplicates.

Table 6: MIC of AgNp's of methanolic extract of Eucalyptus globules.

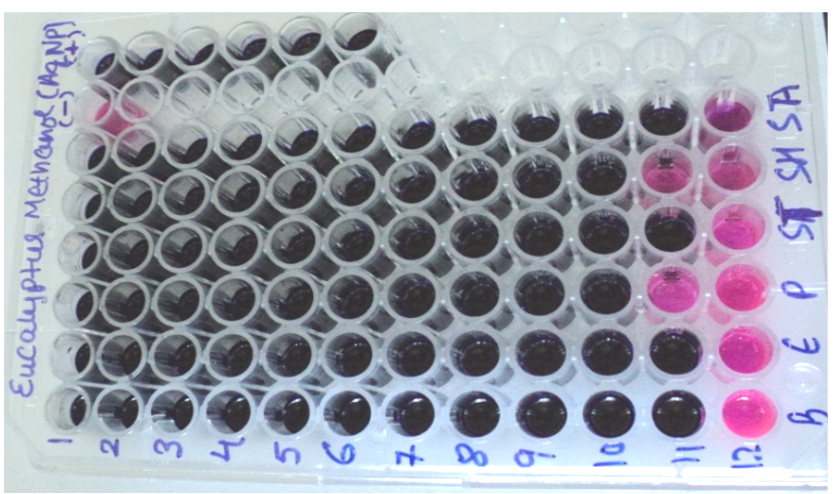

B: B. subtilis; E: E.coli; P: P. aeruginosa; SA: S. typhi; SH: Shigella; ST: S aureus.

Figure 19: MIC results of AgNp's of methanolic extract of Eucalyptus globules.

\begin{tabular}{|c|c|c|}
\hline Microorganism & $\begin{array}{c}\text { Crude methanol extract } \\
\mathbf{( m g / 1 0 0} \mathbf{\mu l})\end{array}$ & $\begin{array}{c}\text { AgNp's of methanol } \\
\text { extract } \mathbf{( m g / 1 0 0} \boldsymbol{\mu l})\end{array}$ \\
\hline B. cereus & 0.078 & 0.0097 \\
\hline E. coli & 0.039 & 0.0097 \\
\hline P. aeruginosa & 0.019 & 0.019 \\
\hline S. typhi & 0.078 & 0.0097 \\
\hline Shigella & 1.25 & 0.019 \\
\hline S. aureus & 0.078 & 0.0097 \\
\hline
\end{tabular}

Table 7: Comparison of MIC of crude extract with silver nanoparticles. 
Citation: Thakur K, Bala I, Rajeshwer, Devi M, Bhatt AK (2017) Evaluation of Effectiveness of Biologically Synthesized Silver Nanoparticles of Eucalyptus globules Leaf Extract against Pathogenic and Acne-inducing Bacteria. J Nanomed Nanotechnol 8: 443. doi: 10.4172/21577439.1000443

Page 8 of 8

of plant origin have been found to possess biological properties such as antiapoptosis, antiaging, anticarcinogenic, antiinflammation, antiatherosclerosis, cardiovascular protection and improvement of endothelial function, as well as inhibition of angiogenesis and cell proliferation activities [14].

Further to enhance the efficacy of crude plant material, simple reproducible and low cost approach for the preparation of stable silver nanoparticles using methanolic extract of E. globules as the reducing, stabilising and capping agent was carried out. Silver nanoparticals were prepared based on their utility in various ayurvedic formulations e.g. Rajat Bhasma and others as these were proved to be effective for human being.

Study carried out by Lalitha et al. [13] revealed that the nanoparticles synthesized from the neem plant showed the maximum peak at $351 \mathrm{~nm}$ and size of the nanoparticles analyzed through particle size analyzer (PSA) was found to be $21.07 \mathrm{~nm}$. Gavhane et al. [11] revealed that the AgNp's synthesized from the neem plant showed maximum peak at $420 \mathrm{~nm}$ and stated that the size of nanoparticles as $43 \mathrm{~nm}$. Moosa et al. [14] reported that the average diameter of AgNp's synthesized from spent tea leaves were between $66-117 \mathrm{~nm}$ as determined using atomic force microscopy (AFM).

The antibacterial activity of silver nanoparticles was checked and it was observed that there was increase in the activity of extract against all microbes used. MIC of silver nanoparticles was very effective even at very low concentrations. The MIC for crude methanol extract and silver nanoparticles was same i.e. $0.019 \mathrm{mg} / 100 \mu \mathrm{l}$ in case of $P$. aeruginosa thus indicating that both were equally effective against this strain. However, the efficacy of AgNp's was much higher in comparison to crude extracts for other pathogens.

\section{Conclusion}

From the present investigation it can be concluded that the Eucalyptus globules leaf extract can be effectively used to control different pathogenic and acne inducing bacterial strains. Since the medicinal plants have enormous therapeutic potential, therefore plantbased preparations with little or no side effects are cyclically returning to complement various modern medications. Therefore widespread and long-term use of antibiotics, which has led to emergence of resistant strains and other side effects, can be overcome by using traditional or herbal formulations which are safe, efficacious and multifunctional. The effectiveness of traditional formulations against various pathogenic strains can be enhanced by technical inputs which will not only help in the validation of treatment methods used by local herbal practitioners but will also increase the effectiveness of phytochemicals through use of modern technology. Further studies are also needed to fully characterize the toxicity and the molecular mechanisms involved with the antimicrobial activity of these nanoparticles. Efforts are also needed to extract/purify/fractionate and characterize the bioactive compounds to enhance the antimicrobial potential of the crude plant extracts. For this advanced techniques like super critical fluid extraction (SCFE) and analysis through gas chromatography (GC), Mass spectroscopy (MS) and NMR spectroscopy can be used and thereafter to go for large scale synthesis of $\mathrm{Ag}, \mathrm{Au}$ and $\mathrm{Fe}$ nanoparticles to utilize their potential fully for the welfare of mankind.

\section{Acknowledgements}

Financial assistance to Ms. Kalpana Thakur, Mr. Rajeshwer and Ms. Mamta Devi in the form of Junior Research Fellowship (JRF) under NMHS Scheme from the Ministry of Environment, Forest and Climate Change (MoEF \& CC), Govt. of India and GB Pant National Institute of Himalayan Environment \& Sustainable Development (GBPNIHESD) is gratefully acknowledged.

\section{References}

1. Veerachari U, Bopaiah AK (2012) Phytochemical investigation of the ethanolic methanolic and ethyl acetate extract of the leaves of six Cassia species. Journal of Pharmacognosy and Herbal Formulations 2: 36-46.

2. Kumar S, Chand G, Sankhyan P (2013) Herbal folk remedies for curing various ailments in lug valley of district Kullu, Himachal Pradesh (N.W. Himalaya) International Journal of Ayurvedic and Herbal Medicine 3: 1308-1314.

3. Essawi T, Srour M (2000) Screening of some Palestinian medicinal plants for antibacterial activity. Journal of Ethnopharmacology 70: 343-349.

4. Leela A, Vivekanandan M (2008) Tapping the unexploited plant resources for the synthesis of silver nanoparticles. African Journal of Biotechnology 7: 3162 3165.

5. Akin MA, Aktumsek, Nostro A (2010) Antibacterial activity and composition of the essential oils of Eucalyptus camaldulensis and Myrtus communis growing in Northern Cyprus. African Journal of Biotechnology 9: 531-535.

6. Arise RO, Malomo SO, Adebayo JO, Igunnu A (2009) Effects of aqueous extract of Eucalyptus globulus on lipid peroxidation and selected enzymes of rat liver. Journal of Medicinal Plants Research 3: 77-81.

7. Nagpal N, Shah G, Arora M, Shri NR, Arya Y (2010) Phytochemical and pharmacological aspects of Eucalyptus genus. International Journal of Pharmaceutical Sciences and Research 1: 28-36.

8. Takahashi, Kokubo, Sakainom (2004) Antimicrobial activities of Eucalyptus leaf extracts and flavonoids from Eucalyptus maculate. Letters in Applied Microbiology 39: 60-64.

9. McNicholl BP, McGrath JW, Quinn JP (2006) Development and application of a Resazurin-based biomass activity test for activated sludge plant management Water Research 41: 127-133.

10. Sofowara A (1993) Screening plants for bioactive agents. In: medicinal plants and traditional medicine in Africa. (2ndedn.) Spectrum books Ltd. Sunshine house, Ibadan; Nigeria.

11. Gavhane A, Padmanabhan P, Kamble SP, Suresh N (2012) Synthesis of silve nanoparticles using extract of neem leaf and triphala and evaluation of their antimicrobial activities. International Journal of Pharmaceutical and Biological Sciences 3: 88-100.

12. Hayat MQ, Khan MA Ahmad M, Shaheen N, Yasmin G et al. (2008) Ethnotaxonomical approach in the identification of useful medicinal flora of Tehsil Pindigheb (District Attock) Pakistan. Ethnobotany Research and Applications 6: 35-62.

13. Lalitha A, Subbaiya R, Ponmurugan P (2013) Green synthesis of silver nanoparticles from leaf extract Azhadirachta indica and to study its antibacterial and antioxidant property. International Journal of Current Microbiology and Applied Sciences 2: 228-235.

14. Moosa AA, Ridha AM, Allawi MH (2015) Green Synthesis of Silver Nanoparticles using Spent Tea Leaves Extract with Atomic Force Microscopy. International Journal of Current Engineering and Technology 5: 1-9.

15. Rai Y, Kaur N, Aheer D, Kaur R, Prasha H (2013) Phytochemical analysis and antimicrobial activity of methanolic extract of Eucalyptus globules. Journal of Microbiology and Biotechnology Research 3: 77-82.

16. Vishnoi NR (1979) Advanced practical chemistry. Ghaziabad-India: Yikas Publication House, PVT Ltd, pp: 447-449.

17. Biljana DV, Tatjana D, Danijela S, Jovanka D (2011) Antimicrobial Effect of Essential Oil Isolated from Eucalyptus globulus Labill. Czech Journal of Food Science 29: 277-284

18. Yadav RNS, Agarwala M (2011) Phytochemical analysis of some medicinal plants. Journal of Phytology 3: 10-14 